УДК 658.012.4

\title{
UNCERTAINTY OF THE INSTITUTIONAL ENVIRONMENT FOR THE SUSTAINABLE DEVELOPMENT OF THE PROCESSING INDUSTRY OF UKRAINE
}

\author{
M. Minenko \\ National University of Food Technologies
}

\begin{tabular}{l} 
Key words: \\
Institutional environment \\
sustainability \\
Processing industry \\
Associations of \\
producers; trade unions \\
Branch agreement \\
Collective agreement \\
Institutional changes \\
\hline
\end{tabular}

Article history:

Received 09.11.2017

Received in revised form

30.11.2017

Accepted 18.12.2017

Corresponding author:

M. Minenko

E-mail:

npnuht@ukr.net

\begin{abstract}
The paper emphates on the necessity of institutional changes to ensure the stability of food security and the development of transparent competitive conditions for the functioning of the processing industry of Ukraine. Such changes were substantiated, taking into account the threats that arose in connection with the monopolization of the product chain by one of its participants, the process of integration into European and world community, and also the "shadowing" of the national economy. The historical steps of reforming food, meat and dairy industry of Ukraine have been analyzed, which in fact led to the elimination of the institutional component, which determined their place and role in the system of economic relations. It is noted that the Department of Food of the Ministry of Agrarian Policy and Food of Ukraine, the association of producers, labor unions of the processing industry neither independently nor institutionaly can minimize losses and systematically defend the interests of owners, employees, consumers. The author's vision of possible institutional changes, which would contribute to the harmonization of the motivation component of the process of cultivation, processing and selling of products, was also determined, as well as the formation of an appropriate environment for the sustainable development of the processing industry of Ukraine was ensured. The forecast of expected benefits for employers and employees in case of signing the Branch Agreement and Collective Agreements is given.
\end{abstract}

DOI: $10.24263 / 2225-2924-2017-23-6-8$

\section{НЕВИЗНАЧЕНІСТЬ ІНСТИТУЦЙНОГО СЕРЕДОВИЩА ДЛЯ СТАЛОГО РОЗВИТКУ ПЕРЕРОБНОÏ ПРОМИСЛОВОСТІ УКРАЇНИ}

\author{
М.А. Міненко \\ Національний університет харчових технологій
}

У статті акцентовано увагу на необхідності проведення інституиійних змін для забезпечення стабільності продовольчої безпеки і створення прозорих кон- 
курентних умов функціонування переробної промисловості України. Обтрунтовано такі зміни, враховуючи загрози, щьо виникли у зв'язку з монополізацією продуктового ланиюга одним із його учасників, прочесом інтегрування в європейський і світовий простір, а також «тінізацією» національної економіки. Проаналізовано історичні кроки реформування харчової, м'ясної і молочної промисловості України, що фактично призвели до ліквідачії інститучійної складової, яка визначала їх місие та роль у системі економічних відносин. Зазначено, що департамент продовольства Міністерства аграрної політики та продовольства України, об'єднання виробників, профспілкові об'єднання переробної промисловості самостійно ні ресурсно, ні інституційно не можуть мінімізувати втрати і системно відстояти інтереси власників, найманих прачівників, споживачів. Визначено авторське бачення можливих інституційних змін, що сприяли б гармонізаиії мотиваційної складової процесу вирощування, переробки і реалізаиії продукції, а також забезпечили створення належного середовища для сталого розвитку переробної промисловості України. Дано прогноз очікуваних переваг для роботодавиів і найманих прачівників у разі підписання галузевої угоди і колективних договорів.

Ключові слова: інституиійне середовище, сталий розвиток, переробна промисловість, виробничі об'єднання, профспілкові об'єднання, галузева угода, колективний договір, інституиійні зміни.

Постановка проблеми. Процес інтегрування в Європейське співтовариство і необхідність забезпечення конкурентоспроможності національного товаровиробника зумовлює потребу здійснення структурних інституційних перетворень, які мають збалансувати інтереси держави, бізнесу, споживача. Дослідження і використання в Україні позитивних практик, вироблення публічного механізму дієвої співпраці головних учасників продуктового ринку, враховуючи національні особливості, забезпечить формування середовища, що сприятиме створенню гарантованої продовольчої безпеки та ефективних умов функціонування моделі сталого розвитку аграрно-промислової сфери.

Саме сучасний стан економіки потребує системного аналізу попереднього періоду, організаційного і методологічного порівняння з механізмами інституційного становлення розвинутих країн світу, напрацювання нових прогресивних пропозицій, що, на нашу думку, дасть можливість мінімізувати втрати ресурсів для побудови на теренах незалежної України фахового інституційно спроможного і соціально відповідального середовища. Належний рівень фаховості, інституційності, соціальної орієнтованості стане основою конкурентоспроможності та інвестиційної привабливості держави в цілому й конкретних промисловостей і секторів національної економіки зокрема. Цим обумовлена актуальність нашого дослідження і необхідність ще раз привернути увагу не тільки науковців, а насамперед представників державних інституцій до проблеми монополізації інституційної вертикалі аграрно-промислової сфери єдиним представником продуктового ланцюга.

Аналіз останніх досліджень і публікацій. Економічні й соціальні доктрини інституціоналізму та його значення у гармонізації економічних інтересів 
розкрито у працях А. Алчіана, Дж. Б’юкенена, М. Вебера, Т. Веблена, Г. Демзеца, Е. Дюркгейма, К. Ерроу, Р. Коуза, Дж. Коммонса, Р. Нельсона, Д. Норта, Р. Познера, О. Шпикуляка та інших. Разом із тим негативність впливу монополії одного і можливі втрати при цьому, що вже сьогодні $є$ відчутними для кожного учасника процесу вирощування, переробки і реалізації продукції кінцевому споживачу, системно науковцями не досліджувалися.

Мета статті: проаналізувати ситуацію, що склалася в Україні на сучасному етапі розвитку, і визначити авторський варіант можливих шляхів формування відповідного інституційного середовища, яке могло б гармонізувати інтереси держави, підприємницьких кіл, споживача для сталості продовольчої безпеки та цивілізованих конкурентних умов функціонування переробної промисловості.

Викладення основних результатів дослідження. Забезпечення споживача якісними, доступними за ціною та у достатньому обсязі харчовими продуктами $\epsilon$ головною стратегічною соціально значимою метою. Цієї мети можна досягнути за умови формування і підтримання на сучасному рівні середовища, що сприятиме ефективному й результативному функціонуванню підприємств переробної промисловості України. По суті, потрібно створити умови для їх сталого розвитку.

На практиці запорукою сталого розвитку промисловостей національної економіки мають бути три складові: інституційна, правова, економічна. Зазначені складові при фахово-збалансованому поєднанні свого впливу на діяльність суб'єктів господарювання конкретної промисловості сприятимуть ix збереженню, захисту, перспективам.

В умовах сьогодення можна констатувати: інституційна складова, що визначала місце та роль національної переробної промисловості в системі економічних відносин і забезпечувала організаційно-правове середовище їх ефективної діяльності, практично ліквідована. Ліквідація Міністерства хлібопродуктів, міністерств харчової, м'ясної і молочної промисловості України, а потім Державного департаменту продовольства призвела до монополізації інституційної вертикалі аграрно-промислового комплексу тільки одним учасником продуктового ланцюга (табл.).

Табличя. Реформування харчової, м'ясної і молочної промисловості України у період 1985-2015 років, сформовано автором з використанням [1]

\begin{tabular}{|c|c|c|}
\hline Форма управління & Роки & Регламентуючий документ \\
\hline 1 & 2 & 3 \\
\hline $\begin{array}{c}\text { Державний аграрно-промисловий } \\
\text { комітет УРСР (Держагропром } \\
\text { УРСР) }\end{array}$ & $1985-1991$ & $\begin{array}{c}\text { Постанова ЦК КПРС та Ради } \\
\text { Міністрів СРСР від 14.11.1985 } \\
\text { № } 1114 \text { (Створений на базі } \\
\text { Мінсільгоспу, Мінплодоовочгоспу, } \\
\text { Мінм’ясомолпрому, Мінхарчопром,, } \\
\text { Мінсільбуду, Мінсільгосптехніки) }\end{array}$ \\
\hline $\begin{array}{c}\text { Держагропром УРСР } \\
\text { Республіканський комітет } \\
\text { харчової та переробної } \\
\text { промисловості (Укрхарчопром): } \\
\text { Головне управління розвитку } \\
\text { м’ясної промисловості }\end{array}$ & $1989-1991$ & $\begin{array}{c}\text { Постанова Ради Міністрів УРСР від } \\
16 \text { жовтня } 1989 \text { року № } 253 \text { «Про } \\
\text { удосконалення управління в } \\
\text { аграрно-промисловому комплексі } \\
\text { республіки» }\end{array}$ \\
\hline
\end{tabular}




\begin{tabular}{|c|c|c|}
\hline \multicolumn{3}{|r|}{ Продовження табл. } \\
\hline 1 & 2 & 3 \\
\hline $\begin{array}{c}\text { Головне управління розвитку } \\
\text { молочної промисловості }\end{array}$ & & $\begin{array}{c}\text { Наказ по Укрхарчопрому від } \\
6 \text { листопада } 1989 \text { року № } 2 \text { «Питання } \\
\text { організації Укрхарчопрому» }\end{array}$ \\
\hline Держагропром УРСР & & $\begin{array}{c}\text { Ліквідований у травні } 1991 \text { p. } \\
\text { Додаток № } 1 \text { до Постанови Кабінету } \\
\text { Міністрів УРСР від 24.05.1991 }\end{array}$ \\
\hline $\begin{array}{l}\text { Міністерство сільського } \\
\text { господарства УРСР }\end{array}$ & $1991-1992$ & \begin{tabular}{|c|} 
Закон УРСР від 13 травня 1991року \\
№ 10306-ХІІ, стаття 1 \\
«Про перелік міністерств та інші \\
центральні органи державного \\
управління УРСР»
\end{tabular} \\
\hline $\begin{array}{c}\text { Державний комітет УРСР з } \\
\text { харчової та переробної } \\
\text { промисловості при Кабінеті } \\
\text { Міністрів УРСР } \\
\text { (Держхарчопром): } \\
\text { Головне управління м’ясної } \\
\text { промисловості; } \\
\text { Головне управління молочної } \\
\text { промисловості }\end{array}$ & $1991-1992$ & $\begin{array}{c}\text { Створений згідно з Постановою } \\
\text { Кабінету Міністрів УРСР від } \\
24 \text { травня } 1991 \text { року № } 12 \text { «Про } \\
\text { порядок реалізації Закону УРСР } \\
\text { «Про перелік міністерств та інші } \\
\text { центральні органи державного } \\
\text { управління УРСР» }\end{array}$ \\
\hline $\begin{array}{l}\text { Республіканський галузевий } \\
\text { концерн м’ясної промисловості } \\
\text { «Укрм’ясо», Республіканський } \\
\text { галузевий концерн молочної } \\
\text { промисловості «Укрмолпром» }\end{array}$ & $1991-1993$ & $\begin{array}{c}\text { Наказ Держхарчопрому УРСР від } \\
12 \text { серпня } 1991 \text { року №12 «Про } \\
\text { створення республіканського } \\
\text { галузевого концерну м’ясної } \\
\text { промисловості «Укрм’ясо». } \\
\text { Наказ Держхарчопрому УРСР від } \\
12 \text { серпня } 1991 \text { року №11 «Про } \\
\text { створення республіканського } \\
\text { галузевого концерну молочної } \\
\text { промисловості «Укрмолпром» } \\
\text { Постанова Кабінету Міністрів } \\
\text { України від } 23 \text { квітня } 1993 \text { року }\end{array}$ \\
\hline $\begin{array}{c}\text { Міністерство сільського } \\
\text { господарства і продовольства } \\
\text { України: } \\
\text { Головне управління м’ясної } \\
\text { промисловості; } \\
\text { Головне управління молочної } \\
\text { промисловості (ліквідовані у } \\
\text { березні } 1997 \text { р.) }\end{array}$ & $1992-1997$ & $\begin{array}{c}\text { Указ Президента України від } \\
25 \text { лютого } 1992 \text { року №98 «Про } \\
\text { зміни у системі центральних органів } \\
\text { державної виконавчої влади } \\
\text { України» }\end{array}$ \\
\hline $\begin{array}{c}\text { Концерн «Укрм’ясо» } \\
\text { Концерн «Укрмолпром» } \\
\text { (у підпорядкуванні } \\
\text { Мінсільгосппроду України) }\end{array}$ & $1992-1993$ & $\begin{array}{c}\text { Наказ Держхарчопрому від } \\
20 \text { березня } 1992 \text { року № } 45 \text { «Про } \\
\text { передачу підприємств і організацій } \\
\text { м’ясної та молочної промисловості } \\
\text { до Міністерства сільського } \\
\text { господарства і продовольства } \\
\text { України» } \\
\\
\text { око }\end{array}$ \\
\hline $\begin{array}{c}\text { Національна асоціація } \\
\text { виробників м’яса та } \\
\text { м’ясопродуктів України } \\
\text { «Укрм'ясо» } \\
\end{array}$ & 1995 & $\begin{array}{c}\text { Створена зборами засновників } \\
19 \text { грудня } 1995 \text { року }\end{array}$ \\
\hline
\end{tabular}




\begin{tabular}{|c|c|c|}
\hline \multicolumn{2}{|c|}{ Закінчення табл. } \\
\hline $\begin{array}{c}\text { Національна асоціація } \\
\text { молочників України } \\
\text { «Укрмолпром» }\end{array}$ & 1995 & 3 \\
\hline $\begin{array}{c}\text { Міністерство аграрно- } \\
\text { промислового комплексу } \\
\text { України }\end{array}$ & $1997-1999$ & $\begin{array}{c}\text { Створена зборами засновників } \\
12 \text { грудня 1995 року }\end{array}$ \\
$\begin{array}{c}\text { 25 червня 1997 року № 693 «Про } \\
\text { утворення Міністерства аграрно- } \\
\text { промислового комплексу України» }\end{array}$ \\
$\begin{array}{c}\text { Міністерство аграрної політики } \\
\text { України }\end{array}$ & 1999 & $\begin{array}{c}\text { Указ Президента України від } \\
\text { грудня 1999 року № 1573/99 «Про } \\
\text { зміни у структурі центральних } \\
\text { органів виконавчої влади» }\end{array}$ \\
\hline $\begin{array}{c}\text { Державний департамент } \\
\text { продовольства Міністерства } \\
\text { аграрної політики України }\end{array}$ & 2000 & $\begin{array}{c}\text { Постанова Кабінету Міністрів } \\
\text { України від 14 березня 2000 року } \\
\text { № 489 }\end{array}$ \\
\hline $\begin{array}{c}\text { Міністерство аграрної політики } \\
\text { та продовольства України }\end{array}$ & 2010 & $\begin{array}{c}\text { Указ Президента України від } \\
\text { 09 грудня 2010 року № 1085/2010 }\end{array}$ \\
\hline $\begin{array}{c}\text { Департамент продовольства } \\
\text { Міністерства аграрної політики } \\
\text { та продовольства України }\end{array}$ & 2015 & $\begin{array}{c}\text { Наказ Міністерства аграрної } \\
\text { політики та продовольства України } \\
\text { від 03 серпня 2015 року № 310 }\end{array}$ \\
\hline
\end{tabular}

Департамент продовольства, що сьогодні представляє інтереси переробників у структурі Міністерства аграрної політики та продовольства України, ні інституційно, ні ресурсно не може дієво впливати на процеси. Як наслідок, намагання керівників окремих виробничих об'єднань самостійно відстоювати інтереси переробників залежать від особистих зв'язків, «гарного настрою» тих державних посадовців, кого вони змушені турбувати через нагальні проблеми, що потребує витрат значних ресурсів для отримання бажаних результатів. Фактично, представники переробної промисловості стали жебраками у власній країні, які за це ще й платять, залишаючись одними з головних донорів зведеного бюджету. Водночас відбувається звільнення («зачищення») вітчизняного ринку харчових продуктів для експансії закордонними товаровиробниками, а угоди зі Світовою організацією торгівлі та Європейським Союзом стають гальмівним фактором для розширення ринків збуту за межами України.

На практиці, за умови реалізації заходів щодо євроінтеграції, однією із найбільш незахищених виявилася переробна промисловість. Обладнання, технології, стандарти, рівень кваліфікації кадрів у більшості випадків не відповідають європейським і світовим вимогам. Термін приведення у відповідність за основними із них спливає протягом 2017 року. Крім того, до 2020 року Європейський Союз планує обмежити пільгові умови для українських товаровиробників і відкрити кордони для вільної торгівлі. До зазначеного вище можна додати: невизначеність державної політики щодо місця та ролі переробників у царині аграрної сфери; проблеми, пов'язані з подоланням квот і сертифікаційних умов при виході на зовнішні ринки; штучний розрив між наукою та виробництвом; всезростаючий дефіцит кваліфікованих кадрів; відсутність сучасної бази для підготовки кадрового резерву тощо. 
Все це створює суттєві загрози і має спонукати роботодавців в Україні об'єктивно оцінити свої перспективи й власні можливості. Яскравим прикладом негативних наслідків для переробної промисловості щодо несвоєчасного реагування роботодавців на європейські умови господарювання та намагання самотужки вирішувати проблеми є досвід Болгарії, Греції, Румунії. Саме в цих країнах збанкрутували цілі галузі, звільнивши власний ринок для закордонних товаровиробників.

Не менш негативними залишаються внутрішні загрози. Так, відповідно до заяв представників влади, близько $50 \%$ бізнесу працює в «тіні», а в переробній промисловості цей показник досягає $70 \%$. Наслідком роботи підприємств у «тіні» $€$ :

- придбання дешевої не сертифікованої сировини;

- застосування хімічних домішок;

- відсутність санітарних умов на виробництві;

- заробітна плата, у кращому випадку, на рівні мінімальної, решта у «конверті»;

- відсутність колективного договору з найманими працівниками.

Такий стан речей не сприяє розвитку підприємств переробної промисловості України, зменшує їх конкурентоспроможність, посилює соціальну напругу в трудових колективах, неминуче веде до банкрутства.

Крім виробничих об'єднань переробної промисловості, захищати інтереси як найманих працівників, так і власників намагаються профспілкові об'єднання, а саме:

- Всеукраїнська профспілка працівників харчової, переробної промисловості та суміжних галузей (свідоцтво про реєстрацію № 2050 від 24.02.2004, репрезентативність пройшла у 2017 р.);

- Всеукраїнська профспілка харчової та переробної промисловості (свідоцтво про реєстрацію №2020 від 31.12.2003, репрезентативність пройшла у 2017 p.);

- Всеукраїнська профспілка «Соціальний прогрес» (свідоцтво про реєстрацію № 1451 від 13.06.2000);

- Всеукраїнська професійна спілка «Співдружність» (свідоцтво про реєстрацію № 650762 від 12.07.2010).

У 2010 році (за ініціативи керівника Всеукраїнської профспілки працівників харчової, переробної промисловості та суміжних галузей, за участю перерахованих профспілок) для забезпечення результативності цієї роботи, а також для ведення переговорів та укладання галузевої угоди в харчовій, хлібопекарській та переробній промисловості України було створено Спільний представницький орган (СПО). На обліку учасників СПО близько 80 тис. членів (майже 300 первинних профспілкових організацій на 300 підприємствах). Географічно профспілкові організації СПО діють у 24 регіонах України.

Попри всі зусилля керівників всеукраїнських профспілок переробників, налагодити плідну співпрацю з Міністерством аграрної політики та продовольства України, Федерацією роботодавців агропромислового комплексу та продовольства України і Профспілкою працівників агропромислового ком- 
плексу України щодо вирішення проблем у переробній промисловості у спосіб конструктивного та рівноправного діалогу - результатів не дало. Фактично мусимо констатувати, що відсутні умови формування фахового, інституційно збалансованого, соціально відповідального, конкурентно прозорого середовища для всіх учасників продуктового ланцюга.

Посилюються загрози для підприємств переробної промисловості ще й у зв'язку з підписанням нової редакції Генеральної угоди про регулювання основних принципів і норм реалізації соціально-економічної політики i трудових відносин в Україні (від 23 серпня 2016 року) [2]. Загрози пов'язані 3 тим, що всі суб'єкти господарювання на території України підпадають під норми цієї угоди. У випадку їх невиконання будуть застосовуватися відповідні штрафні санкції.

Мусимо констатувати, що за останні роки на національному ринку з'явилася тенденція серед окремих власників проводити кампанію з ліквідації на підприємствах переробної промисловості первинних профспілкових організацій. Відсутність профспілкової організації дає підстави не укладати колективний договір між роботодавцями і найманими працівниками. Це, на нашу думку, спричинено нерозумінням того, що, відстоюючи нагальні потреби найманого працівника, можна отримати середовище, яке за своїм рівнем фаховості i соціальної відповідальності сприятиме саме розвитку, а не стагнації. Тимчасові «переваги» для власника, у разі відсутності партнера в особі профспілки, досить швидко перетворяться на втрати, безпосередньо пов'язані із ставленням до виконання своїх обов'язків найманих працівників і відповідною оцінкою продуктів, що пропонуються для реалізації, споживачем.

У цивілізованих країнах продукція підприємства-виробника, що не має первинної профспілкової організації та не входить до складу репрезентативного соціально відповідального профспілкового об'єднання, викликає недовіру. Саме тому при маркуванні готової продукції, крім зазначення конкретного стандарту якості, на відповідність якого сертифіковане виробництво, вказується приналежність до конкретного профспілкового об'єднання, чим підкреслюється ставлення власника до питань соціальної відповідальності. Такій продукції споживач надає перевагу. Враховуючи зазначене, крім унеможливлення штрафних санкцій щодо невиконання умов Генеральної угоди, власники мають додаткову інституційну можливість підвищити конкурентні переваги своїх підприємств. Це можна реалізувати через процедуру підписання галузевої угоди, що своїм змістом збалансує соціально-економічні інтереси роботодавця і найманого працівника та сприятиме отриманню додаткових прибутків.

Підписантами такої Галузевої угоди, відповідно до норм Законів України «Про колективні договори і угоди», «Про соціальний діалог в Україні», «Про організації роботодавців, їх об’єднання, права і гарантії їх діяльності» [3 -5], повинні бути репрезентативні інституції: з одного боку, об'єднання роботодавців, з іншого - профспілкове об'єднання. Сьогодні для підприємств переробної промисловості репрезентативний підписант з боку найманого працівника визначений, а репрезентативний підписант з боку роботодавця (власника), який може відслідковувати його інтереси, — не визначений. 
За обставин, коли сільгоспвиробники і їх монопольні інституції прямо демонструють небажання враховувати інтереси всіх учасників продуктового ланцюга, ми пропонуємо реалізувати на практиці новий формат взаємовідносин. Цей формат передбачає створення громадської інституції переробників, яка має бути репрезентативною відповідно до Закону України «Про соціальний діалог в Україні» від 23 грудня 2010 року № 2862-VI та забезпечить координування дій для захисту інтересів саме переробної промисловості на державному та місцевому рівнях. Така інституція надаватиме послуги своїм учасникам за напрямами, які вони самі визначатимуть, а також запропонує умови для зменшення непередбачуваних ризиків впливу зовнішнього середовища. 3 огляду на це пропонуємо створити репрезентативне об'єднання роботодавців переробної промисловості та суміжних галузей.

Активна робота такої громадської інституції переробників надасть можливість системно вирішувати питання взаємовідносин роботодавців і найманих працівників через процедуру підписання Галузевої угоди та колективних договорів, до змісту яких буде включено пункти, що збалансують інтереси підписантів і забезпечать:

- роботодавцю економію до $20 \%$ прибутку і фонду оплати праці, за умови фінансування соціального пакета колдоговору через профспілку, що реально відстоює їх інтереси;

- додаткове зменшення на $10-20 \%$ податкового навантаження на підприємства, що будуть членами профспілки (залежно від розміру суб'єкта господарювання) завдяки тому, що профспілка неприбуткова організація i більшість виплат із ііі бюджету не обкладаються податком (фактично все, що роботодавець і профспілка визначать за умовами колективного договору);

- профспілці можливість виступати третьою стороною при вирішенні спірних питань між роботодавцем і державними інституціями для захисту економічних та соціальних інтересів роботодавців. Профспілка може висловити таку точку зору, яку роботодавцю, за певних обставин, буде зробити проблематично;

- спільне представлення інтересів і вплив на діяльність будь-якого державного органу через процедуру участі в діяльності громадських рад та інших публічних інституцій;

- спільне ініціювання розробки проектів законів і підзаконних актів та громадський супровід їх прийняття й реалізацію;

- проведення фахової експертизи й відстоювання спільних інтересів, беручи участь у процесі громадського обговорення і прийняття за основу проектів законів та інших нормативно-правових актів, що пропонують суб'єкти законодавчої ініціативи та інші заінтересовані сторони;

- проведення узгоджених заходів з обговорення і забезпечення захисту економічних та соціальних інтересів роботодавців і трудових колективів (інтерв'ю, прес-конференції, круглі столи, форуми, інші акції);

- вирішення інших питань, що будуть стояти на порядку денному.

Головною метою діяльності такого репрезентативного об'єднання має бути набуття правового статусу фахового, самоврядного і саморегулівного, що дасть можливість підприємствам переробної промисловості стати рівно- 
правними суб'єктами публічного впливу при визначенні перспектив свого розвитку.

\section{Висновки}

Інституційне середовище створюється людьми. Люди розвивають i змінюють інститути, враховуючи об'єктивні умови господарювання. Водночас інституційні зміни визначають те, як суспільство вважає за доцільне розвиватися в часі. Попри все, формування відповідного цивілізованого інституційного поля $є$ однією з основних передумов ефективного функціонування промисловостей. Системне розуміння такого простору цілеспрямує дії всіх учасників, дасть змогу об'єктивно оцінити реалії щодо інституційної спроможності та вибрати раціональні шляхи іiі розбудови й місце кожної зацікавленої сторони у цьому процесі.

\section{Література}

1. Міненко М.А. Фахові виробничі об’єднання (теорія, методологія, практика) : монографія. - Київ : ННЦ ІАЕ, 2010. - 358 с.

2. Генеральна угода про регулювання основних принципів і норм реалізації соціальноекономічної політики і трудових відносин в Україні // Урядовий кур'єр. — 14.09.2016. № 172. - (Нормативний документ Кабінету Міністрів України, ФПУ, інших. Угода, регламент, перелік, порядок від 23 серпня 2016 року № 0001120-16).

3. Про колективні договори і угоди // Урядовий кур'єр. - 31.07.1993. - (Нормативний документ Верховної Ради України. Закон від 01 липня 1993 року № 3356-XII).

4. Про соціальний діалог в Україні // Урядовий кур'єр. - 16.02.2011. —№ 29. - (Нормативний документ Верховної Ради України. Закон від 23 грудня 2010 року № 2862-VI).

5. Про організації роботодавців, їх об'єднання, права і гарантії їх діяльності // Урядовий кур’єр. - 22.08.2012. — № 151. - (Нормативний документ Верховної Ради України. Закон від 22 червня 2012 року № 5026-VI). 